(c) The Author(s), 2021. Published by Cambridge University Press on behalf of The College of Psychiatrists of Ireland This is an Open Access article, distributed under the terms of the Creative Commons Attribution licence (http://creativecommons.org/licenses/by/4.0/), which permits unrestricted re-use, distribution, and reproduction in any medium, provided the original work is properly cited. doi:10.1017/ipm.2021.39

CORRIGENDUM

\title{
An approach to teaching psychiatry to medical students in the time of Covid-19 - Corrigendum
}

\author{
A. Guerandel, N. McCarthy, J. McCarthy, D. Mulligan, A. Lane and K. Malone
}

https://doi.org/10.1017/ipm.2020.87, Published by Cambridge University Press, 02 July 2020

When originally published, this article didn't include two of the authors. These authors have now been added and the article has been corrected.

The authors apologise for this oversight.

\section{Reference}

Guerandel, A., McCarthy, N., McCarthy, J., Mulligan, D., Lane, A., \& Malone, K. (2020). An approach to teaching psychiatry to medical students in the time of Covid-19. Irish Journal of Psychological Medicine, 1-7. doi: 10.1017/ipm.2020.87 